УДК 378:355:371

UDC 378:355:371

DOI: 10.31475/ped.dys.2018.24.07

МАЙЯ КАРПУШИНА,

кандидат педагогічних наук

(Украӥна, Хлельницький, Національна академія Державної прикордонної служби України ілені Богдана Хлельницького, вул. Шевченка, 46)

MAIIA KARPUSHYNA,

candidate of pedagogical sciences (Ukraine, Khmelnytskyi, State Border Guard Service of Ukraine named after Bohdan Khmelnytskyi,

Shevchenko str., 46)

ORCID: 0000-0002-9480-0070

\title{
Теоретичні основи технології проблемного навчання студентів у закладах вищої освіти
}

\section{Theoretical Foundations of Students' Problem-based Learning Technology in Higher Educational Establishments}

У статті з’ясовано особливості проблелного навчання як технологї̈, визначено ї̈ характеристики та потенціал в освітньолу процесі вищого навчального закладу. Уточнено сутність поняття технологї проблелного навчання. Технологія проблелного навчання - ие техніка реалізації навчального процесу, детерлінованого проблелною ситуацією, яка визначає відповідно інтегровані способи організацї проблелного викладання та проблелного учіння на всіх ї̈ етапах розв'язання та рівнях проблелності, летою якої є оволодіння певнили способали розв'язання проблел на рівні улінь і навичок мисленнєвої діяльності. Виявлено теоретичні основи технологї проблелного навчання, серед яких такі як: теорія законолірності розвитку мислення; теорія методів навчання; проблелна ситуація; проблелне навчальне середовище; суб'єкт-об’єт-суб’єктна взаєлодія ліж учасникали навчального процесу; зміст освіти міждисииплінарного характеру.

Ключові слова: проблелне навчання, проблелна ситуація, педагогічна технологія, систела методів, приниипи, мислення.

In the article the peculiarities of problem-based learning as a technology are determined, its characteristics and potential in the educational process of the higher educational establishments are defined.

Thus, problem-based learning is an approach to professional education that stresses the use of reallife problems as a stimulus for learning, which is considered contextually valid, in the sense that the problems are taken from professional practice. As a result, students acquire knowledge organized around these problems being involved with reality; learn social and communicative skills in genuine discourse, which explains the rationale behind their actions.

The definition of the problem-based learning technology has been clarified. Problem-based learning technology is a learning process implementation procedure, determined by the problem situation, which defines accordingly the integrated ways of organizing problem-based teaching and problem-based learning at all stages of problem-solving as well as autonomous levels, the purpose of which is to master certain problem-solving methods at the level of skills and abilities of mental activity. It has been explored that the origin of the problem-based learning is obliged to the development of the theory of teaching methods, and its didactic characteristic reflects the structure and function of the evolving education methods. Therefore, the detailed arguments for revealing theoretical basis of the system of problemsolving methods have been advanced, including the principles on which they are founded. The following basic principles have been selected: goal-oriented, situation-based and problem-solving learning, binary approach, theory and practice relationship, consciousness and intelligibility, active engagement, autonomy, and emotionality.

The theoretical foundations of the problem-based learning technology are revealed. Among those foundations there is a theory of thinking development patterns, theory of teaching and learning methods, problem situation, problem-based learning environment, subject-object-subject interaction between participants of the educational process, interdisciplinary education content.

The most challenging aspects of the future research in this area will concern the study of ways to efficiently combine problem-solving methods and to organize the educational process by the "problem scenarion.

Key words: problem-based learning, problem situation, pedagogical technology, system of methods, principles, thinking. 
Вступ / Introduction. Спосіб педагогічного мислення у XX столітті за визнанням ЮНЕСКО визначали такі педагоги як Дж. Дьюї, Г. Кершенштейнер, М. Монтесорі й А. Макаренко. На їхне переконання, основний акцент освітнього процесу покладався на навчання через свідому практичну діяльність, опанування знань у дії, тобто вмінь розв'язувати задачі або завдання 3 практичного життя; самостійне й логічне мислення; втілення принципу зв'язку навчання і життя 3 урахуванням професійних інтересів учнів та вміння співпрацювати.

Сьогодні, переступивши поріг XXI століття, вітчизняні та зарубіжні науковці і педагогипрактики ще й досі шукають шлях утілення цих актуальних ідей у практику освітньої діяльності. Національна доктрина розвитку освіти в Україні, реагуючи на сучасні реалії життя, висувае перед педагогами завдання формування компетентних, самостійних, ініціативних і відповідальних членів суспільства, здатних свідомо діяти, приймати власні рішення, швидко адаптуватися до змін. Вирішення цього завдання можна вважати найкращим результатом будь-якої педагогічної технології. Саме така технологія і визначатиме спосіб педагогічного мислення XXI століття. На нашу думку, цією технологією є проблемне навчання, для якого «характерні такі якості як: ефективність, технологічність, своєчасність, адекватність сучасним дидактичним засобам навчання» (Левіна М., 2001) та сучасним викликам професійній діяльності майбутніх фахівців. 3 цієї причини зростає потреба у розробці технології проблемного навчання (далі - ПН), яка фрормує у студентів едність професійних рішень з науково обгрунтованими практичними діями, розуміння професійних завдань i технології їх розв'язання на концептуальному, процедурному i реалізуючому рівнях (Левіна М., 2001). А беручи до уваги те, що низка дослідників умовно поділяє все навчання на проблемне і непроблемне (Левіна М., 2001), то наш вибір не є безпідставним.

Проблемне навчання і сьогодні залишається одним із центральних напрямів педагогічних досліджень. Значний внесок у дослідження теорії ПН здійснили А. Алексюк, В. Андреєв, які розглядали методику впровадження ПН в освітній процес вищої школи, М. Левіна, яка вважає організацію ПН одним із центральних завдань вузівської методики навчання й засобом формування у студентів едності професійних рішень з науково обтрунтованими практичними діями, розуміння професійних завдань i технології їх розв'язання на концептуальному, процедурному i реалізуючому рівнях. Вона дійшла висновку, що своїм походженням ПН зобов'язане розвитку теорії методів навчання, а його дидактична характеристика відображає структуру і фрункцію методів розвивального навчання. Значний доробок у дослідження ПН вніс М. Махмутов, який вивчав як сутність проблемної ситуації (далі - ПС), так і практичний досвід педагогів, які запроваджували ї в освітню діяльність. Теорію ПН активно розробляли і зарубіжні науковці, серед яких М. Баден, Г. Беркель, К Вілкі, Г. Шмідт. Вони досліджували потенціал ПС у профресійній підготовці майбутніх фахівців, зміст ПС, характер взаємодії між об'єктом і суб'єктом навчання тощо.

Мета та завдання / Aim and tasks. Метою цієї статті е з'ясування особливостей проблемного навчання як технології й визначення їі теоретичних основ. Досягнення ціеї мети передбачає виконання таких завдань: визначити сутність і особливості змісту ПН на основі аналізу психологопедагогічної літератури й обгрунтувати теоретичні основи технології ПН.

Методи / Methods. Для реалізації поставленої мети використано такі методи: теоретичні аналіз і узагальнення наукової літератури - для уточнення змісту ПН як технології; системноструктурний аналіз психолого-педагогічних праць - для простеження розвитку педагогічної думки 3 проблеми дослідження; порівняння, синтез та абстрагування - 3 метою обгрунтування теоретичних основ ПН, формулювання і систематизації висновків, визначення подальших наукових розвідок.

Результати / Results. Психологічною основою ПН стала теорія мислення як продуктивного процесу, висунута С. Рубінштейном. Ї̈̈ розвивали К. Абульханова-Славська, А. Брушлинський, І. Ільницька, Т. Кудрявцев, О. Матюшкін, Н. Менчинська, А. Фурман. Центральне місце ціеї теорії займае твердження про те, що ПС провокуе мислення. «Мислення зазвичай починаеться 3 проблеми або запитання, з подиву або нерозуміння, із суперечності. Цією ПС визначається включення особистості у розумовий процес» (Рубінштейн С., 2002).

Теоретичні розробки ПН е вельми різнобічними. Вчені вкладають різний зміст у поняття «проблемне навчання». Думки вчених розділилися, але більшість з них вважають його сукупністю певних дій, тобто описують характер діяльності ПН, де викладач створюе певне пізнавальне завдання, допомагае студентам виокремити і прийняти його, організовуе їх для його розв'язання; студенти самостійно оволодівають певною сумою знань, умінь (Л. Зьома, А. Кузьмінський, І. Лернер, В. Омеляненко).

Різні підходи до трактування ПН свідчать про значні прогалини у дослідженні як теорії, так і практики організації ПН (табл/ 1). 
Трактування поняття «проблемне навчання»

\begin{tabular}{|c|c|}
\hline Проблемне навчання - це & Автор \\
\hline $\begin{array}{l}\text { діяльність, що моделюе процес мислення і має пошуковий характер, } \\
\text { навчання за допомогою постановки проблемних завдань, створення і } \\
\text { вирішення проблемних ситуацій }\end{array}$ & $\begin{array}{l}\text { Л. Кондрашова, } \\
\text { О. Пермяков }\end{array}$ \\
\hline метод навчання & $\begin{array}{l}\text { В. Оконь, I. Зайцева, } \\
\text { А. Брушлинський }\end{array}$ \\
\hline $\begin{array}{l}\text { характер навчання, якому надають деяких суттевих рис наукового } \\
\text { пізнання }\end{array}$ & Д. Вількеєв \\
\hline тип навчального процесу & $\begin{array}{l}\text { А. Алексюк, З. Курлянд, } \\
\text { Р. Хмелюк, А. Семенова }\end{array}$ \\
\hline $\begin{array}{l}\text { тип розвивального навчання, зміст якого представлено системою } \\
\text { проблемних задач або завдань різного рівня складності }\end{array}$ & В. Кудрявцев \\
\hline $\begin{array}{l}\text { тип розвивального навчання, в якому поєднуються систематична } \\
\text { самостійна пошукова діяльність учнів з засвоєнням ними готових } \\
\text { висновків науки, а система методів побудована з урахуванням } \\
\text { цілепокладання й принципу проблемності; процес взаємодії } \\
\text { викладання і навчання }\end{array}$ & M. Max \\
\hline $\begin{array}{lcccc}\begin{array}{l}\text { психолого-педагогічна } \\
\text { пізнавального процесу }\end{array} & \text { система } & \text { в } & \text { організації } & \text { навчально- } \\
\end{array}$ & $\begin{array}{l}\text { Л. Волчегурський, } \\
\text { В. Максимова }\end{array}$ \\
\hline $\begin{array}{l}\text { конструктивістський підхід до професійного навчання, який } \\
\text { грунтуеться на використанні проблем реального життя у навчанні }\end{array}$ & $\begin{array}{l}\text { J. M. Henk, } \\
\text { H. Van Berkel, } \\
\text { H. G. Schmidt }\end{array}$ \\
\hline $\begin{array}{l}\text { процес послідовного і цілеспрямованого висунення перед студентами } \\
\text { пізнавальних завдань }\end{array}$ & М. Фіцула \\
\hline $\begin{array}{l}\text { організація навчальних занять, яка передбачае створення під } \\
\text { керівництвом викладача проблемних ситуацій і активну самостійну } \\
\text { діяльність студентів у їх вирішенні }\end{array}$ & Г. Селевко \\
\hline $\begin{array}{l}\text { системна організація навчального плану певними частками навколо } \\
\text { проблемних ситуацій, які допомагають студентам як набувати знань, } \\
\text { так і досвіду в розв'язуванні проблем }\end{array}$ & $\begin{array}{l}\text { W. J. Stepien, } \\
\text { S. A. Gallagher, } \\
\text { D. Workman }\end{array}$ \\
\hline $\begin{array}{l}\text { технологія розвивального навчання, яка спрямована на отримання } \\
\text { студентами знань, формування прийомів дослідницької пізнавальної } \\
\text { діяльності, на залучення студентів до наукового пошуку, творчості; } \\
\text { на виховання професійно-значимих якостей особистості й } \\
\text { опанування професійних умінь } \\
\end{array}$ & $\begin{array}{l}\text { М. Левина, Г. Ксензова, } \\
\text { І. Дичківська }\end{array}$ \\
\hline
\end{tabular}

На нашу думку, наведені визначення ПН лише описують одну або ж кілька складників ПН, що входять до більш глобальної парадигми - технології ПН. По-перше, як тип навчання воно описуе лише процес, сукупність певних дій; по-друге, ПН використовуе цілу систему методів, а тому не може розглядатися якимось одним методом навчання; по-трете, ПН може мати місце й у позааудиторний час, тому передбачає не лише організацію навчальних занять; по-четверте, ПН використовує різні підходи до організації навчального процесу, отже й вони входять до структури ПН; по-п'яте, педагогічна технологія - складова процесуальної частини дидактичної системи, тобто система навчання є багаторівневою будовою (Чошанов М., 1996) й може використовувати різні методики у взаемодії, різні технології, різні типи навчання. Відповідно намагання звести сутність ПН до діяльності, спрямованої на розв'язання ПС, до принципу проблемності, особливої форми взаємодії або проблемного методу не мають жодних підстав, оскільки вони входять до структури ПН, яке слід вважати технологією. Ми повністю погоджуемося з тими авторами, які трактують ПН як технологію.

За нашими спостереженнями, ПН має не лише всі ознаки технологічності, але й виконуе завдання педагогічної технології: відпрацювання глибини і міцності знань, опанування знань i вмінь у різних сферах діяльності; відпрацювання й опанування соціально цінних форм і звичок поведінки; навчання дій з технологічним інструментарієм; розвиток технологічного мислення, вмінь самостійно планувати свою самоосвітню діяльність; виховання звички чіткого виконання вимог технологічної дисципліни в організації навчальних занять і суспільно корисної праці (Ліхачов Б., 1998).

ПН виконуе ці завдання педагогічної технології завдяки таким особливостям: пізнавальній самостійності студентів, стійким мотивам навчання і способам діяльності, детермінованих 
системою проблемних ситуацій; процесу взаємодії викладання і навчання, який орієнтований на формування світогляду студентів (Махмутов М., 1972); практичній діяльності, у процесі якої студенти оволодівають новими знаннями і способами дій, завдяки чому відбуваеться формування творчих здібностей (продуктивного мислення, уяви, пізнавальної мотивації, інтелектуальних емоцій); необхідності самостійних розумових дій; використанню знань монодисциплінарного та міждисциплінарного характеру як умови природної ситуативної взаемодії різних дисциплін у професійній підготовці ВНЗ (Карпушина М., 2017); взаемодії між учасниками навчального процесу, їх соціалізації.

Крім завдань Б. Ліхачов виокремлюе основні характеристики педагогічної технології (Ліхачов Б., 1998), серед яких е такі: технологія розробляеться під конкретну педагогічну задумку, їі основу складае певна методологічна, філософська позиція автора; технологічний ланцюг педагогічних дій і операцій вибудовується суворо у відповідності з цільовими вказівками (установками), які мають форму певного очікуваного результату; функціонування технології передбачає взаємопов'язану діяльність викладача i студентів із урахуванням принципів індивідуалізації та диференціації; поетапне планування і послідовне втілення елементів педагогічної технології повинні бути, з одного боку, - відтворюваними кожним викладачем i, 3 іншого, - гарантувати досягнення планованих результатів усіма студентами; діагностичні процедури, які містять критерії, показники та інструментарій зміни результатів діяльності (Ліхачов Б., 1998).

Виникае логічне запитання, - чи притаманні ці характеристики ПН? Ми переконані, що задумкою ПН е навчити розв'язувати ПС, а відтак мислити проблемно, тобто критично оцінювати ситуацію та приймати рішення i, таким чином, завдяки власній діяльності вносити зміни у дійсність. Іншими характеристиками, які б відповідали технологічності, е наявність системи методів з урахуванням цілепокладання; особлива взаємодія між учасниками навчального процесу та індивідуальний і диференційований підхід до завдань; використання посильних і вельми складних проблем та зв'язок між наявними знаннями й новими, які потрібно засвоїти; продуктом процесу розв'язання проблемної ситуації $е$ не лише знання, а й уміння здобувати знання.

Ураховуючи те, що ПН своїм походженням зобов'язане розвитку теорії методів навчання, а його дидактична характеристика відображае структуру і функцію методів розвивального навчання (Левіна М., 2001), головне завдання сучасного етапу у розвитку ПН, на нашу думку, полягае в тому, щоб розкрити теоретичні основи системи методів ПН. Логічним є припущення, що ретельне вивчення правил добору методів, способів введення методів у навчальний процес, варіативності методів, їх раціональне поєднання, домінування окремих методів, поеднання методів із найбільш ефективними формами організації навчання та різними формами наочності й інші питання, пов'язані $з$ педагогічним менеджментом й особливостями навчальної діяльності, дозволить створити теоретичну базу для компетентної організації ПН і творчого застосування методів. Саме тому вибір методів завжди детермінований суспільно важливими цілями, змістом освіти, враховуе принципи дидактики та включае систему прийомів виховного впливу на студента (Махмутов М., 1972).

Технологія ПН, будучи системою методів, грунтується на таких принципах: цілеспрямованості й бінарності, ситуативності та проблемності, зв’язку теорії та практики, свідомості й активності, доступності, самостійності й емоційності.

Перший у цьому переліку принцип відображає передбачувані результати свідомо організованої діяльності, другий - діяльність викладача та студентів.

Детальніше розглянемо принципи ситуативності та проблемності. Принцип ситуативності rрунтується на таких положеннях: навчання повинно відбуватися на основі і за допомогою ситуацій; змістовою стороною ситуації слід вважати проблеми особистісно або професійно-значимі для студентів (Карпушина М., 2017); навчання логіки викладу думки та мовлення, в цілому, не $е$ можливим поза ситуацією; «маркованість» лексичних одиниць ситуацією або комунікативним завданням породжуе здатність перенесення знань і вмінь у нову ситуацію; варіативність умов ситуації ставлять перед слухачем кожен раз нові завдання; ситуація сприяе розвитку цілеспрямованості - завдяки наявності розумової задачі та продуктивності - завдяки необхідності кожен раз створювати новий продукт (Пасов С., 1991).

Вихідні положення принципу проблемності визначаються такими завданнями у навчальному процесі як: виявлення й урахування рівнів розвитку інтелектуальної сфери студентів; спрямування освітнього процесу на розвиток у них творчих здібностей, пізнавальних умінь та інших компонентів інтелектуальної сфери; створення проблемних ситуацій з урахуванням інтелектуальних можливостей студентів, розв'язання навчальних й інших проблем; структурування взаємодії викладача і студентів згідно з логікою ПН; систематичне здійснення аналізу результативності педагогічних впливів у розвитку інтелектуальної сфери 
(Мельнікова Е., 1999). Рівень інтелектуальної активності у процесі проблемного засвоєння знань і вмінь визначаеться рівнями проблемності (Махмутов М., 1972), до яких відносяться: 1)проблемний виклад, в умовах якого викладач будуе свое повідомлення у формі відтворення логіки пошуку, висування гіпотез, їх обюрунтування і перевірки, а також - оцінки отриманих результатів; 2)проблемна ситуація створюеться викладачем, а проблема фрормулюеться і вирішуеться студентами самостійно; 3)студенти самостійно формулюють і розв'язують проблему; 4)студенти самі розпізнають проблему і вирішують їі (Курлянд 3., 2005). Логічно, що кожен із рівнів проблемності демонструє рівень самостійності студентів, і відповідає певному методу.

Наприклад, А. Алексюк (Алексюк А., 1998) за основу класифікації бінарних методів бере такі ознаки як характер і рівень пізнавальної самостійності й активності студентів і джерела, з яких вони отримують знання. Він визначае чотири рівні їх застосування: на інформаційному (або догматичному) рівні словесна форма набувае бінарного характеру словесно-інформаційного методу; на проблемному (або аналітичному) рівні - бінарного характеру словесно-проблемного методу; на евристичному (пошуковому) рівні - бінарного характеру словесно-евристичного методу; на дослідницькому - характеру словесно-дослідницького методу.

Для освітнього процесу, який грунтуеться на принципі проблемності, характерним $є$ використання методів, властивих логіщі, зокрема, аналітичного, синтетичного, аналітикосинтетичного, індуктивного, дедуктивного та індуктивно-дедуктивного. Ці методи визначають діяльність як викладача, так і студентів, але частка їх застосування у цій технології потребуе уточнень. Так, М. Махмутов уважає, що провідним методом у розв'язанні проблемної ситуації (далі - ПС) повинен стати дедуктивний метод (Махмутов М., 1972). Важко з ним не погодитися, адже він передбачає перехід у пізнанні від загального до конкретного, тобто від ПС до виявлення проблеми або проблем, від проблеми до ії деталей. Разом з тим, зазначений метод не сприяе вирішенню суперечностей, тому розв'язання ПС потребуе цілої системи методів, і без порівняння, аналогії, узагальнення, конкретизації тощо неможливо досягти реалізації завдань навчання.

Ба більше, можна сміливо стверджувати, що у сучасній методиці роль інтерактивних методів навчання стала провідною. Їх сутність полягає в тому, що навчальний процес відбувається за умов постійної, активної взаемодії всіх студентів. Це співнавчання, взаємонавчання (колективне, групове навчання у співпраці) (Пометун О., 2002).

Результати досліджень педагогів-практиків доводять, що запровадження інтерактивних методів сприяе залученню кожного студента до активної взаємодії з навколишнім світом, формуванню вмінь співпрацювати та взаємодіяти один з одним, розвитку їхньої ініціативи і творчого потенціалу, а також формуванню установки на творчу професійну діяльність, розвиток оперативних професійних умінь. Це також запобігае втомлюваності, створюе комфортне середовище для навчання та виховання, забезпечуе умови для формування професійно значущих якостей, що виявляються в умінні управляти власним емоційним станом, виховуе відповідальність за свою роботу, почуття взаємоповаги, обов'язку, гуманності, впевненості у власних силах. 3 іншого боку, ці методи дозволяють студентам поліпшити якість комунікативних умінь, підвищити рівень культури дискусії та володіння головними мисленневими операціями - аналізом, синтезом, узагальненням, абстрагуванням, розвинути навички критичного мислення (Кирилюк В., 2011).

Тому е закономірним, що ключем успішного впровадження технології ПН е, з одного боку, організація змісту навчання навколо проблемного сценарію, а не навколо предмета; з іншого здатність викладача «написати» такий сценарій і дотримуватися правила «навчатися в процесі участі в цьому сценарії» та спонукати його «виконавців» самостійно йти до мети. За таким сценарієм студенти працюють у невеликих групах і їхне завдання не має на меті знайти «правильні відповіді», а - включитися у проблемну ситуацію й прийняти рішення щодо стратегії дій, тобто яка інформація потрібна і які вміння потрібно формувати, щоб ефективно впоратись із проблемною ситуаціею.

Важливим принципом навчального процесу є також принщип емоційності навчання. На думку C. Рубінштейна, емоції суттево впливають на перебіг діяльності і відіграють роль внутрішньої спонукальної сили у навчальній діяльності. Емоційні процеси забезпечують передусім енергетичну основу діяльності, e їі мотивами. Емоції визначають якісну і кількісну характеристику поведінки. Вони також забезпечують селективність сприймання - вибір об’ектів середовища, які впливають на людину і мають для неї значення (Вітенко І., 2010). У системі колективної раціональної діяльності важливо підтримувати позитивні емоції, які знімають м'язове напруження, комунікативні бар'ери, дозволяють особистості почуватися розкуто.

Серед методів стимулювання інтересу до навчання і мотивації навчально-пізнавальної діяльності слід назвати діалог, дискусію, мозковий штурм, метод Дельфі, метод аналізу конкретних ситуацій, ділові ігри, які називають інструментами ПН. Ці методи передбачають групові форми роботи і позитивно впливають на загальну атмосферу навчальної діяльності. Крім 
того, почуття групової належності дає, з одного боку, почуття емоційної та інтелектуальної підтримки, тобто безпеки, а з іншого - почуття відповідальності за кооперативні дії у напрямі досягнення мети. «Де необхідні спільні дії, де потрібна взаємодія, щоб досягти поставлених групових цілей, відбувається процес залучення індивіда до навчання, вироблення компетентності, яка необхідна для групи» (Пометун О., 2004).

Разом із тим, оцінку ефективності будь-якого типу навчання забезпечують методи контролю $\mathrm{i}$ самоконтролю. Самоконтроль у процесі перевірки розв'язання проблем означає усвідомлене регулювання студентом своеї діяльності з метою забезпечення таких результатів ціеї діяльності, які відповідали би поставленим цілям. Мета самоконтролю - розвивати рефлексивне ставлення до власного навчання.

Обговорення / Discussion. Беручи до уваги дослідження вище згаданих науковців, ми маемо всі підстави стверджувати, що ПН - це технологія, яка має всі відповідні характеристики й виконуе її завдання. На нашу думку технологія ПН - це техніка реалізації навчального процесу, детермінованого ПС, яка визначає відповідно інтегровані способи організації проблемного викладання та проблемного учіння на всіх $\dddot{1 i ̈ ~ е т а п а х ~ р о з в ' я з а н н я ~ т а ~ р і в н я х ~ п р о б л е м н о с т і, ~ м е т о ю ~}$ якої е оволодіння певними способами розв'язання проблем на рівні умінь і навичок мисленневої діяльності (Карпушина М., 2017).

Методи технології ПН грунтуються не лише на створенні проблемних ситуацій, активній пізнавальній діяльності студентів, які знаходяться в пошуках і розв'язках складних запитань, що вимагають актуалізащії знань, аналізу, вміння бачити за окремими фактами явища, закономірності і закони (Ніколенко Л., 2005), але й на таких дидактичних принщипах як цілеспрямованість і бінарність, проблемність і ситуативність, зв'язок теорії та практики, усвідомлення й активність, доступність, самостійність й емоційність. Разом з тим обрати найефективніший метод на підставі лише дидактичної мети неможливо, тому що за однієї й тіеї ж мети заняття, але за різного змісту навчального матеріалу, різного рівня проблемності слід використовувати різні методи, орієнтуючись на пізнавальні можливості студентів, наявність засобів навчання, рівень власної педагогічної майстерності тощо (Карпушина М., 2017).

Обов'язковою умовою процесу розв'язання ПС є систематичне поступове ускладнення самої ПС. Необхідним е рух по шкалі рівня складності проблеми, що визначається співвідношенням відомого і невідомого, частки творчої участі у розв’язанні проблеми (Китайгородська Г., 1986). Цей “рух» потрібно пов'язувати з інтенсифікацією процесу взаємодії студента з ПС, підвищенням його інтересу, активності, творчої самостійності в межах групових форм навчання, коли його предметом є спілкування (ставлення суб’єкта до об’екта навчання змінюеться ставленням до суб’єкта спілкування з приводу об’єкта). Тому ПС е об’єктом суб’єкт-об’ект-суб’єктної взаємодії і займає особливе місце у ПН.

Чимало питань виникае щодо змісту ПС. Шляхом демонстрації причинно-наслідкових зв'язків між складниками ПН Г. Беркель і Г. Шмідт довели, що зміст проблеми $є$ його ключовим складником, оскільки прямо або опосередковано впливае на всі інші складники, рівно як і на зростання інтересу студентів до навчальної дисципліни, тому вважають їі питанням детального дослідження (Henk J., 2000). Наш досвід показав, що зміст ПС повинен моделювати зміст майбутньої професійної діяльності студентів й проблем, що належать до потенщійного кола їхніх інтересів, а отже повинен «виходити за межі» одніеї навчальної дисципліни.

Висновки / Conclusions. Таким чином, узагальнення наукових підходів дає підставу зробити висновок, що ПН е технологією, а її теоретичними основами слід вважати: теорію закономірності розвитку мислення або моделювання процесу мислення; теорію методів навчання; проблемну ситуацію; проблемне навчальне середовище як дидактичну умову ПН; суб’ект-об’ект-суб’єктну взаємодію між учасниками навчального процесу; зміст освіти міждисциплінарного характеру як умови природної ситуативної взаемодії різних дисциплін у професійній підготовці студентів.

До перспективних напрямів досліджень у цій сфері ми відносимо вивчення способів контролю й оцінювання результатів навчання студентів за «проблемним сценарієм».

Список використаних джерел і літератури/References:

1. Henk, J. M. Van Berkel, Henk, G. Schmidt (2000) Motivation to Commit Oneself as a Determinant of Achievement in Problem Based Learning Higher Education. Retrieved from https://www.researchgate.net/publication/263684971_Motivation_to_commit_oneself_as_a_determinant_of_achieve ment_in_problem-based_learning [in English]

2. Алексюк, А. М. (1998). Педагогіка вищої освіти України. Історія. Теорія. Київ: Либідь / Aleksiuk, A. M. (1998). Pedahohika vyshchoi osvity Ukrainy. Istoriia. Teoriia. [Pedagogics of Higher Education of Ukraine. History. Theory]. Kyiv: Lybid [in Ukrainian]
3. Вітенко, I. C.
(2010).
Основи
психологіï.
Взято
3

http://pidruchniki.com/1931071037363/psihologiya/emotsiyi_pochuttya\#548 / Vitenko, I. S. (2010). Osnovy 
\begin{tabular}{lllll}
\hline \hline psyholohii & [Fundamentals & of & Psychology]. & Retrived
\end{tabular} http://pidruchniki.com/1931071037363/psihologiya/emotsiyi_pochuttya\#548 [in Ukrainian]

4. Карпушина, М. Г. (2017). Формування у майбутніх офбіцерів-прикордонників умінь розв'язувати проблемні ситуацї у профбесійній діяльності. (Автореф. дис. ... канд. пед. наук). НАДПСУ ім. Б. Хмельницького. Хмельницький / Karpushyna, М. Н. (2017). Formuvannia u maibutnikh ofitserivprykordonnykiv umin rozviazuvaty problemni sytuatsii u profesiinii diialnosti [Formation of Future Border Guard Officers' Abilities to Solve Problem Situations in Professional Activity]. (Extended abstract of Candidate's thesis). NADPSU im. B. Khmelnytskoho. Khmelnytskyi [in Ukrainian]

5. Кирилюк, В. В. (2011). Мета, зміст та принципи підготовки майбутніх обіцерів-прикордонників інтерактивними технологіями з дисциплін гуманітарного ииклу. Взято з http://archive.nbuv.gov.ua/portal/soc_gum/Znpkhist/2011_4/11kvvdgc.pdf / Kyryliuk, V. V. (2011). Meta, zmist ta pryntsypy pidhotovky maibutnikh ofitseriv-prykordonnykiv interektyvnymy tekhnolohiiamy $\mathrm{z}$ dystsyplin humanitarnoho tsyklu [Purpose, Content and Principles of Preparing Future Border Guard Officers by Interactive Technologies in Humanitarian Disciplines] Retrived from http://archive.nbuv.gov.ua/portal/soc_gum/Znpkhist/2011_4/11kvvdgc.pdf [in Ukrainian]

6. Китайгородская, Г. А. (1986). Активизация учебной деятельности студентов как проблема и задача вузовской педагогики. А. В. Петровский (Ред.) Основы педагогики и психологии высшей школьь (с. 197-208). Москва: изд-во МГУ / Kytaigorodskaia, G. А. (1986). Aktivizatsiya uchebnoy deyatelnosti studentov kak problema i zadacha vuzovskoy pedagogiki [Activization of Students' Educational Activity as a Problem and Task of University Pedagogy]. A. V. Petrovskii (Red.) Osnovy pedagogiki i psikhologii vysshey shkoly. Moscow: Izd-vo MGU [in Russian]

7. Курлянд, 3. Н. (Ред.). (2005). Педагогіка вищої школи (2-ге вид.). Київ: Знання / Kurliand, Z. N. (Ed. et al). (2005). Pedahohika vyshchoi shkoly [Pedagogy of Higher Educational Establishments]. (2-ge vyd.). Kyiv: Znannia, 2005 [in Ukrainian]

8. Левина, М. М. (2001). Технологии пробессионального педагогического образования. Москва: Издательский центр «Академия» / Levina, M. M. (2001). Tehnologii professionalnogo pedagogicheskogo obrazovaniia [Technologies of Professional Pedagogical Education]. Moscow: Izdatelskiy tsentr "Akademiia» [in Russian]

9. Лихачев, Б. Т. (1998). Педагогика. Курс лекций. Москва: Юрайт / Lihachiov, В. Т. (1998)ю Pedagogika. Kurs lektsiy [Pedagogy. Course of Lectures]. Moscow: Yurait [in Russian]

10. Махмутов, М. И. (1972). Проблемное обучение. Основныље вопросы теории. Казань / Mahmutov, M. I. (1972). Problemnoe obucheniie. Osnovnyie voprosy teorii [Problem-Based Learning. Basic Issues of the Theory]. Kazan [in Russian]

11. Мельникова, Е. Л. (1999). Технология проблемного обучения. Школа 2100. Образовательная програмла, 3, 85-93 / Melnykova, Ye. L. (1999). Tehnologiia problemnogo obucheniia. Shkola 2100 [Technology of Problem-based Learning. School 2100]. Obrazovatelnaiia programma, 3, 85-93 [in Russian]

12. Ніколенко, Л. Т. (2005). Особистісно орієнтована освіта: проблеми та шляхи реалізації в системі підвищення кваліфікації. Ученье записки, 3, 23-27 / Nikolenko, L. T. (2005). Osobystisno oriientovana osvita: problemy ta shliakhy realizatsii v systemi pidvyshchennia kvalifikatsii [Person-Oriented Education: Problems and Ways of Implementation into the System of Professional Development]. Uchioniye zapiski, 3, 23-27 [in Ukrainian]

13. Пассов, Е. И. (1991). Комлуникативный метод обучения иностранному говорению. Москва: Просвещение / Passov, Y. I. (1991). Kommunikativnyi metod obucheniia inostrannomu govoreniiu [Communicative Method of Foreign Language Teaching]. Moscow: Prosveshcheniie [in Russian]

14. Пометун, О. І. \& Пироженко, Л. В. (2002). Інтерактивні технології навчання: теорія і практика. Київ / Pometun, O. I. \& Pyrozhenko, L. V. (2002). Interaktyvni tekhnolohii navchannia: teoriia i praktyka [Interactive Learning Technologies: Theory and Practice]. Kyiv [in Ukrainian]

15. Пометун, О. І. \& Пироженко, Л. В. (2004). Сучасний урок. Інтерактивні технології навчання. Київ: вид-во А. С. К. / Pometun, О. I. \& Pyrozhenko, L. V. (2004). Suchasnyi urok. Interaktyvni tekhnolohii navchannia [Modern Lesson. Interactive Learning Technologies]. Kyiv: Vyd-vo A. S. K [in Ukrainian]

16. Рубинштейн, С. Л. (2002). Основы общей психологии. Санкт-Петербург: Издательство Питер / Rubinshtein, S. L. (2002). Osnovy obshchei psyhologii [Fundamentals of General Psychology]. Saint-Petersburg: Izdatelstvo Piter [in Russian]

17. Чошанов, М. А. (1996). Гибкая технология проблемно-модульного обучения. Москва: Народное образование / Choshanov, M. А. (1996). Gibkaia tehnologiia problemno-modulnogo obucheniia [Flexible Technology of Problem-Modular Learning]. Moscow: Narodnoe obrazovanie [in Russian]

Дата надходження статті: «30» березня 2018 p.

Стаття прийнята до друку: «10» травня 2018 р.

Карпушина Майя - старший викладач кафедри перекладу Національної академії Державної прикордонної служби України імені Богдана Хмельницького, кандидат педагогічних наук

Karpushyna Maiia - senior lecturer of the department of translation of National Academy of the State Border Guard Service of Ukraine named after Bohdan Khmelnytskyi, candidate of pedagogical sciences

\section{Цитуйте цюю статтю як:}

Карпушина, М. (2018). Теоретичні основи технології проблемного навчання студентів у закладах вищої освіти. Педагогічний дискурс, 24, 50-56.

\section{Cite this article as:}

Karpushyna, M. (2018). Theoretical Foundations of Students' Problem-based Learning Technology in Higher Educational Establishments. Pedagogical Discourse, 24, $50-56$. 